\title{
Induction of cell proliferation in old rat liver can reset certain gene expression levels characteristic of old liver to those associated with young liver
}

\author{
Muhammad A. Chishti • Namik Kaya • \\ Al-Bandary BinBakheet • Falah Al-Mohanna • \\ Malcolm H. Goyns • Dilek Colak
}

Received: 18 September 2011 / Accepted: 14 March 2012 /Published online: 4 April 2012

(C) The Author(s) 2012. This article is published with open access at Springerlink.com

\begin{abstract}
During the past decade, it has become increasingly clear that consistent changes in the levels of expression of a small cohort of genes accompany the aging of mammalian tissues. In many cases, these changes have been shown to generate features that are characteristic of the senescent phenotype. Previously, a small pilot study indicated that some of these changes might be reversed in rat liver, if the liver cells became malignant and were proliferating. The present
\end{abstract}

Muhammad A. Chishti and Dilek Colak contributed equally to this work.

\footnotetext{
M. A. Chishti · F. Al-Mohanna

Department of Comparative Medicine, King Faisal

Specialist Hospital and Research Centre,

Riyadh, Saudi Arabia 11211

N. Kaya $\cdot$ A.-B. BinBakheet

Department of Genetics,

King Faisal Specialist Hospital and Research Centre,

Riyadh, Saudi Arabia 11211

M. H. Goyns

Children's Cancer Center,

King Faisal Specialist Hospital and Research Centre,

Riyadh, Saudi Arabia 11211

D. Colak $(\bowtie)$

Department of Biostatistics,

Epidemiology and Scientific Computing,

King Faisal Specialist Hospital and Research Centre,

Riyadh, Saudi Arabia 11211

e-mail: dcolakkaya@kfshrc.edu.sa
}

study has tested the hypothesis that inducing proliferation in old rat liver can reset the levels of expression of these age-related genes to that observed in young tissue. A microarray approach was used to identify genes that exhibited the greatest changes in their expression during aging. The levels of expression of these markers were then examined in transcriptomes of both proliferating hepatomas from old animals and old rat liver lobes that had regenerated after partial

D. Colak

email: dkcolak@gmail.com

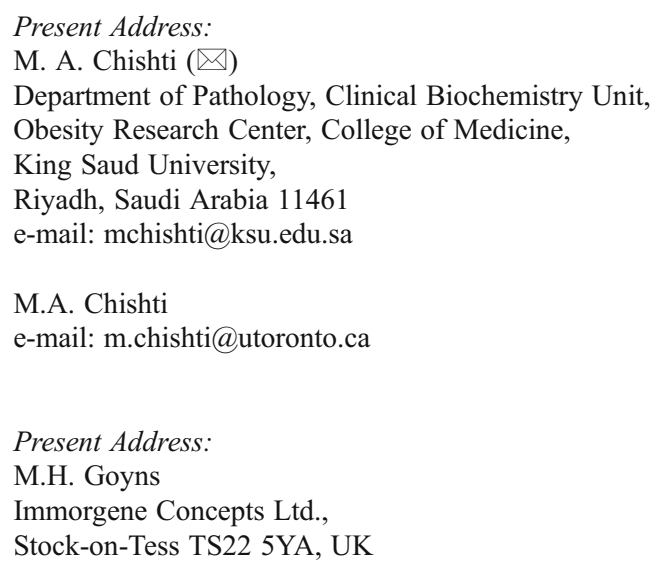


hepatectomy but were again quiescent. We have found evidence that over $20 \%$ of the aging-related genes had their levels of expression reset to young levels by stimulating proliferation, even in cells that had undergone a limited number of cell cycles and then become quiescent again. Moreover, our network analysis indicated alterations in MAPK/ERK and Jun-N-terminal kinase pathways and the potential important role of $P A X 3, V C A N, A R R B 2, N R 1 H 2$, and ITGA5 that may provide insights into mechanisms involved in longevity and regeneration that are distinct from cancer.

Keywords Liver - Aging · Hepatectomy · Microarray Global gene expression · Regeneration · Longevity

\section{Introduction}

It has become increasingly clear that changes in the expression levels of certain genes accompany the aging of mammals. Over a decade ago, studies using the differential display technique demonstrated that approximately $1 \%$ of all active genes exhibit such agerelated changes, some increasing during aging and others decreasing (Goyns et al. 1998; Salehi et al. 1996). An important observation from these early studies was that the genes involved were consistent from individual to individual and in some cases from species to species (Goyns 2002). The advent of microarray technology allowed these general conclusions to be confirmed, but also provided a far more rapid identification of the genes exhibiting these agerelated changes. Most importantly, the microarray studies demonstrated that the changes in gene expression were delayed in animals that had been subjected to calorie restriction diets (Lee et al. 1999, 2000; Li et al. 1997; Kume et al. 2010). As a calorie restriction diet is the only experimental procedure that can consistently extend life span in mammals (Masoro 1992), these studies lend support to the hypothesis that changes in gene expression levels are important in the development of the senescent phenotype (Swindell 2008).

More recently, changes in gene expression have been reported in a wide range of tissues, including brain ( $\mathrm{Lu}$ et al. 2004), kidney (Rodwell et al. 2004; Kume et al. 2010), liver (Cao et al. 2001; Mori et al. 2007), fibroblasts(Ly et al. 2000), cardiac muscle (Lee et al. 2002), and skeletal muscle (Welle et al. 2003).
These studies have studied species as diverse as mice (Cao et al. 2001; Lee et al. 2002), monkeys (Kayo et al. 2001), and humans (Welle et al. 2003). Increasingly, these gene expression changes are being linked to physiological aging (Rodwell et al. 2004; Zahn et al. 2006).

It is intriguing to question whether it is possible to develop an intervention that could have an anti-aging effect. The application of calorie restriction diets in mice has already demonstrated that a general slowing of these gene expression changes can be achieved (Cao et al. 2001; Lee et al. 1999). Also, a small pilot study has reported that some of the age-related changes in gene expression observed in rat liver appear to be reversed in hepatoma cells derived from old animals (Charlton et al. 1999; Tanaka et al. 2002). In the latter study, it was not clear whether the reversal effect was related to the hepatoma cells being malignant or whether it was a result of the cells actively proliferating.

In present study, we investigated the hypothesis that stimulation of cell proliferation in old livers can reset age-related gene expression levels to those observed in young liver using a microarray approach. We analyzed the transcriptomes of proliferating hepatoma cells, regenerated old liver, and normal aging liver in a rat model using a microarray of more than 27,000 annotated genes from Celera and public repositories. Hence, we explored possible molecular links between regeneration, cancer, and longevity: common genes, networks, and pathways associated with aging, regeneration, and cancer.

\section{Materials and methods}

\section{Animals}

A colony of Sprague Dawley rats was maintained at the King Fahad National Centre for Children's Cancer and Research animal house, which is managed in accordance with AALAS regulations. A total of 60 rats, including 30 young rats at the age of 5 months and 30 old rats at the age of 22 months were used in this study. These young rats were grouped as normal young (denoted as NY), drug-induced hepatoma (DY), and regenerating liver by partial hepatectomy (RY), each consisting of 10 rats. Similarly, 30 old rats were grouped as normal old (NO), drug-induced 
hepatoma (DO), and regenerating liver by partial hepatectomy (RO), each consisting of 10 rats.

Ten rats from the young and old age groups were subjected to partial hepatectomy. Briefly, a midline ventral abdominal skin incision was made, and a small bolster was placed under the thorax causing the liver to fall slightly forward away from the diaphragm; then, the ligaments attaching the liver to the diaphragm were cut down. A piece of gauze was placed near the incision, and the left lateral and median lobes were moved out from the abdominal cavity. These lobes were lifted vertically, blood vessels were tied then laid on the gauze, and a cut was made to bleed on the gauze, not into the abdominal cavity, and finally transected. The bolster was removed, and the skin incisions were closed (Wayneforth 1980). The remaining liver lobes were allowed to undergo the regeneration process, which was completed within 1 month, by which time the liver cells had again become quiescent. This was confirmed by a histological analysis of sections from the liver. The rats were sacrificed after 1 month of partial hepatectomy, and samples were collected from four rats in each group.

In parallel, young and old rats (10 each) were treated with diethylnitrosoamine $(200 \mathrm{mg} / \mathrm{kg})$, which was injected intraperitoneally to induce the formation of a hepatoma (Ito et al. 1989). Tumor formation became apparent within 4 weeks. The rats were sacrificed, and samples were collected. All tissues were snap frozen and stored at $-80^{\circ} \mathrm{C}$ until required for RNA isolation. Small pieces of tissue were also removed from the regenerated lobes and hepatoma foci at the same time, subjected to formalin fixation, and examined histologically after hematoxylin and eosin staining. Samples were collected from a minimum of four rats in each group. We used four individual animals in each group (DO, DY, RO, RY, $\mathrm{NO}$, and NY) for further study.

\section{RNA isolation}

RNA was prepared from the rat tissue samples using the Trizol protocol (Invitrogen, Carlsbad, CA, USA). Total RNA quality and quantities were determined by measuring the absorbance spectra on a UV/vis spectrophotometer, the NanoDrop ${ }^{\circledR}$ ND-1000 Spectrophotometer (Nanodrop Inc., Wilmington, DE, USA), and further analyzed by an RNA 6000 Nano Assay using the 2100 Bioanalyzer (Agilent Technologies, Santa Clara, USA).
The undegraded, higher-quality RNA was processed further for RT-PCR and microarray experiments.

\section{Microarray hyridization}

Whole-genome gene expression profiling of 24 samples from hepatoma cells (DO, DY; $n=8)$, regenerated liver (RO, RY; $n=8)$, and normal liver (NO, NY; $n=8$ ) using Applied Biosystems Rat Genome Survey Microarray (Applied Biosystems, Foster City, CA, USA) contains more than 27,000 gene sequences based on 60-mer oligonucleotide probes. Digoxigenin-UTPlabeled cRNA was generated and amplified from $2 \mu \mathrm{g}$ total RNA from each sample using applied Biosystems Chemiluminescent RT-IVT labeling kit v 1.0 (Applied Biosystems, Foster City, CA, USA) following the manufacturer's protocol. Array hybridization was performed for $16 \mathrm{~h}$ at $55^{\circ} \mathrm{C}$. Chemiluminescence detection, image acquisition, and analysis were performed using Applied Biosystems Chemiluminescence Detection Kit and the Applied Biosystems 1700 Chemiluminescent Microarray Analyzer (Applied Biosystems, Foster City, CA, USA), following the manufacturer's protocol.

Microarray data analysis

Images were auto-gridded, the chemiluminescent signals were quantified, and the background subtracted using the Applied Biosystems 1700 Chemiluminescent Microarray Analyzer software v 1.1. For transcriptome analysis, detection thresholds were used following the manufacturer's recommendations. Detection threshold was set as $\mathrm{S} / \mathrm{N}>3$ and quality flag $<5,000$. Various Bioconductor packages were used for normalization and determination of differentially expressed genes (Gentleman et al. 2004). Significantly modulated genes were defined as those with absolute fold change $>2.0$ and an analysis of variance (ANOVA) $p$ value $<0.05$. Human hepatocellular carcinoma (HCC) datasets from independent studies were analyzed as described previously (Colak et al. 2010). The hierarchical clustering of differentially expressed genes using Pearson's correlation with average linkage clustering was performed using the TIGR Multi Experiment Viewer (Saeed et al. 2003), and heatmaps were generated with red and green indicating high and low expression, respectively. 
Functional annotation and biological term enrichment analysis was performed by using the protein analysis through evolutionary relationships (PANTHER) classification system (Thomas et al. 2003). For each molecular function, biological process, or pathway term, PANTHER calculates the number of genes identified in that category in both the list of differentially regulated genes and a reference list containing all the probe sets present on the AB Human Genome Survey Microarray and compares these results using the binomial test to determine if there are more genes than expected in the differentially regulated list (Thomas et al. 2006). Overrepresentation was defined by a $p$ value $<0.05$. Functional pathway and gene interaction network analyses were executed using Ingenuity Pathways Analysis (IPA) 6.3 (Ingenuity Systems, Mountain View, CA). Statistical analyses were performed with the MATLAB software packages (Mathworks, Natick, MA, USA), R/Bioconductor, and PARTEK Genomics Suite (Partek Inc., St. Louis, MO, USA).

\section{Real-time RT-PCR}

In order to validate our microarray results, confirmatory real-time RT-PCR was performed using the ABI 7500 Sequence Detection System (ABI, Foster City, CA, USA). For this purpose, 50 ng total RNA procured from the same microarray study samples was transcribed into cDNA using Sensiscript Kit (QIAGEN Inc., Valencia, CA, USA) according to the manufacturer's recommendations. Eight differentially expressed genes were randomly selected and primers designed using Primer3 software (Table 1). After primer optimization, the PCR assays were performed in $6 \mu \mathrm{l}$ of the cDNA using the QIAGEN QuantIT SyBR Green Kit, employing GAPDH as the endogenous control gene. All reactions were conducted in triplicates, and the data were analyzed using the delta delta $C_{T}$ method (Livak and Schmittgen 2001).

\section{Results}

Global gene expression profiling of normal aging liver, hepatoma, and regenerated old liver

We analyzed whole-genome mRNA expression profiling of hepatoma cells, regenerated liver from old rats, and normal liver of both young and old rats using Applied Biosystems Rat Genome Survey microarray which includes more than 27,000 annotated genes. First, we indentified normal aging signature genes by comparing the transcriptomes of normal young and old livers. The ANOVA identified 1,300 probes (corresponding to 397 up- and 519 downregulated genes) as differentially expressed in normal old compared to normal young ( $p$ value $<0.05$ and absolute fold change of $>2.0$ ). The levels of expression of these genes were then compared to the hepatomas derived from old liver and the regenerated old liver by using overlapping gene lists (Fig. 1a). When comparing two groups of samples to identify genes differentially expressed in a given group, we used $p$ value and the fold change (FC) between two groups as the cutoff criteria. If the $p$ value is $<0.05$ and the absolute FC between the groups is $>2.0$, the corresponding gene was considered differentially expressed between the two groups. Each circle in the Venn diagram represents the differential expression between two "treatment" types (Fig. 1a). The red circle (left) shows the 1,300 normal aging genes that are differentially expressed between NO and NY; 142 and 154 of those genes were also differentially expressed in regenerated liver (RO) and hepatomas from old liver, respectively,
Table 1 Nucleotide sequences used in real-time RT-PCR validation of randomly selected genes identified by microarray analysis

\begin{tabular}{lll}
\hline Gene & Forward primer & Reverse primer \\
\hline Ube216 & GGTGAGAAGGCAGGACTCTG & TTTTGTGAGTCATCAACAGAAAAT \\
Wit3 & TCCAGCAAGAAAACAGACAAA & TCCTTTGAGTGCTGCTCCTT \\
Caskin1 & TACTACATCCCAGGCCAGCA & TGGATGCTGTTCAAGTACCG \\
Cltb & GGAACCTGCAACCTGTCTGT & CGAGAAAGCTAAGGTTCCCC \\
Esm1 & TTGCCTCCTGAGAAACAGAA & GGTTCTCAAACACTCCTACATGG \\
Nrp1 & AACTGGTCTGGATGGTGGTC & AACCACATTCCTCAGGAGGA \\
Cap350 & ACACCCCGTGCAGCTCTTAG & GAAGTCCCATGTATACCCTGTAAA \\
E2F5 & TTGACCAGCAGAAGTTGTGG & ATTCAGGCACCCTCTGGTAC \\
\hline
\end{tabular}


a

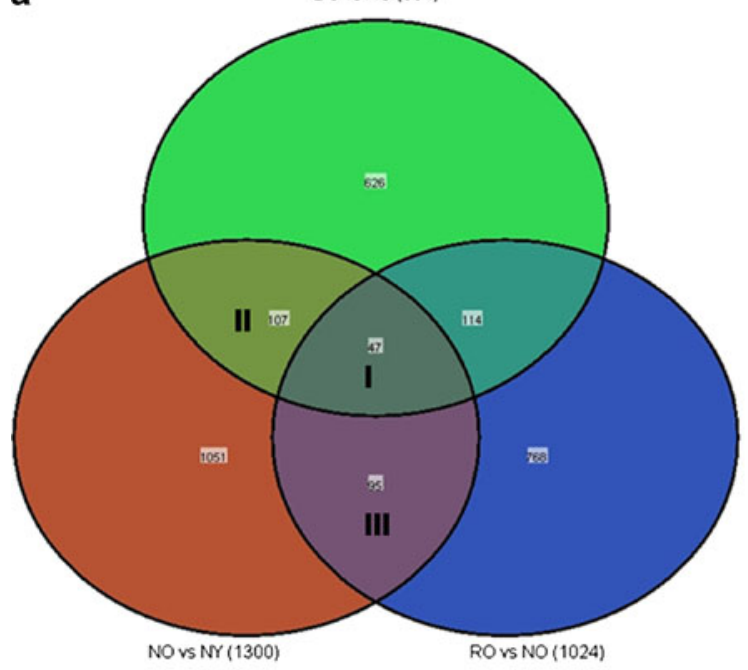

c

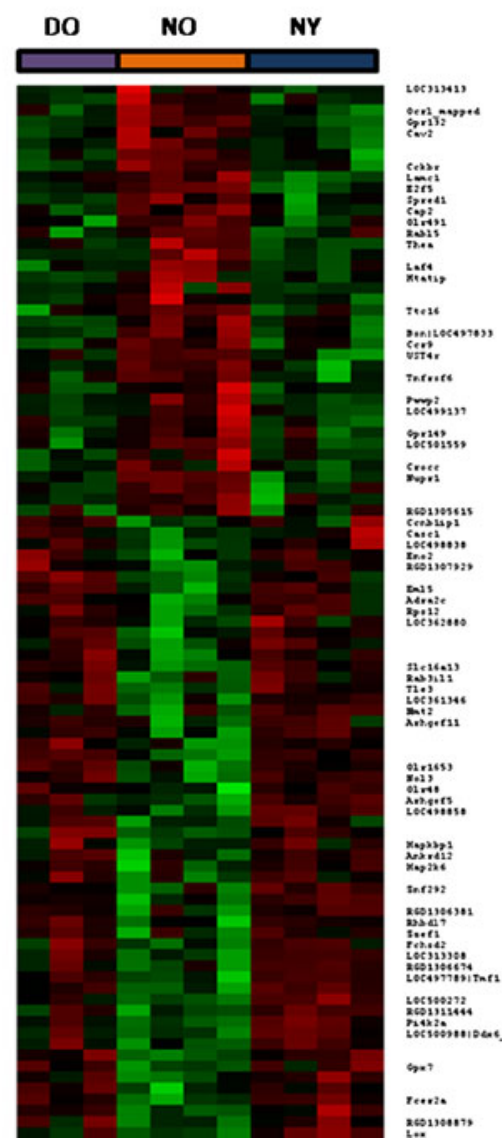

Fig. 1 a Venn diagram indicating the significantly regulated gene overlaps for three comparisons. $\mathbf{b}-\mathbf{d}$ Heatmaps of genes in the intersection I, II, and III indicated in the Venn diagram (Fig. 1a), respectively. Gene symbols are listed on the right. In heatmaps, rows represent genes, and columns represent samples b

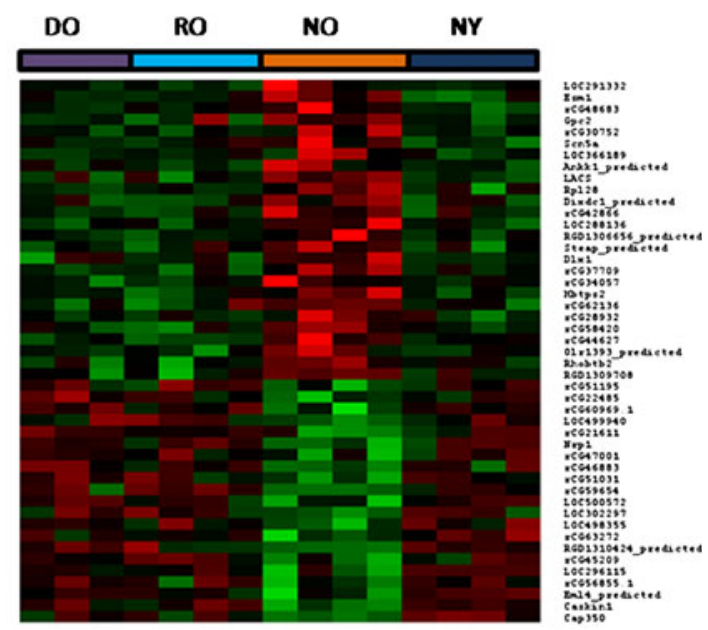

d

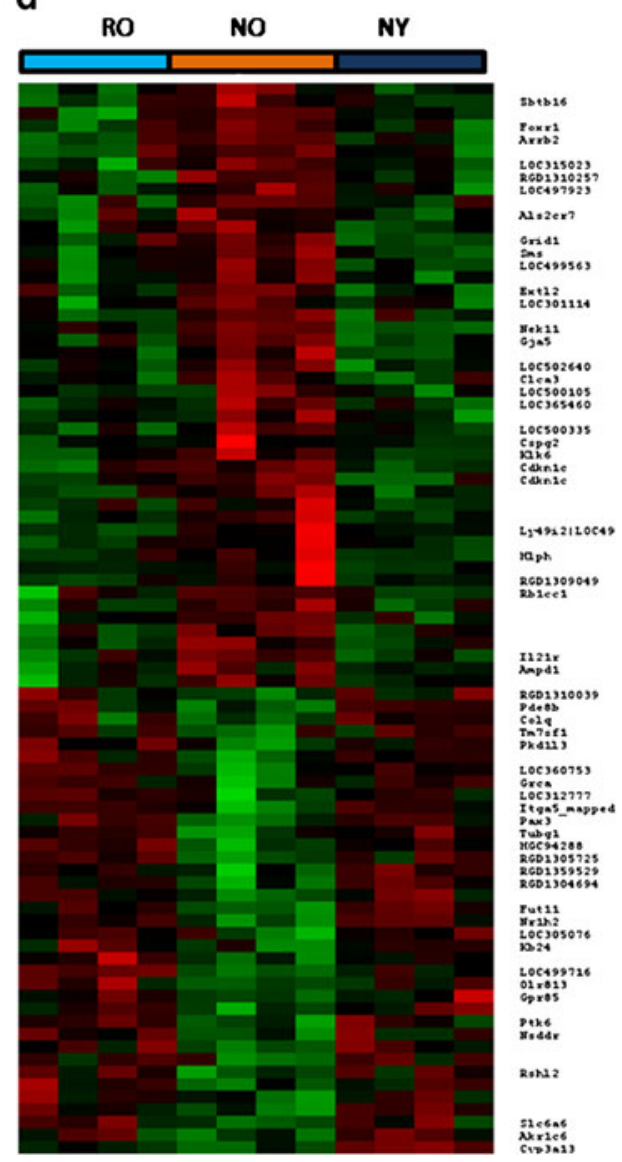

from DO (hepatoma in old), RO (regeneration in old), NO (normal old), and NY (normal young) groups. Genes are clustered using row normalized signals and mapped to the $[-3,3]$ interval. Red and green represent high and low expression values, respectively 
47 of which were common to all comparisons (Fig. 1a, listed in Table 2). It is clearly seen from the heatmaps that over $90 \%$ of genes commonly dysregulated in aging and hepatoma as well as in regeneration have similar levels of expression as in normal young liver (NY), but not from normal old liver (NO) (Fig. 1b-d), where red indicates high levels of expression and green indicates low levels of expression. Intriguingly, we identified 95 aging genes that are significantly dysregulated in the regenerated old liver; however, their expressions in the regenerated old liver were reversed (Fig. 1a, region III, and Fig. 1d). This excludes the 47 aging genes that were also dysregulated in hepatomas from old liver (Fig. 1a, region I). Indeed, as in the hepatoma, expression levels of over $90 \%$ of aging genes in the regenerated old liver were also reset to those seen in the normal young liver (Fig. 1d). The heatmap of those genes were shown in Fig. 1d and listed in Table 3. Importantly, this set of genes corresponds to ones that are exclusively due to cells that had undergone proliferation (in old liver), but not due to cells undergoing malignancy (hepatoma) and have similar level of expression to those seen in the normal young liver.
Gene ontology analyses of aging and regenerated old liver transcriptome

To delineate which biological processes are significantly overrepresented in normal aging and regenerated signature genes, we performed gene ontology and biological term enrichment analyses using both the PANTHER classification system and the Ingenuity Pathway Analysis (IPA). Intriguingly, genes related to immune response, cell adhesion, nervous system and development, and response to stress were found to be activated with aging. On the other hand, genes involved with lipid metabolism, cellular growth and maintenance, protein synthesis, and cellular communication were downregulated. The regeneration-specific genes, however, were mainly associated with lipid metabolism, mRNA transcription and regulation, protein modification, protein phosphorylation, cell morphology, cellular development, small molecule biochemistry, and cellular growth and proliferation. Thus, the genes and processes activated or repressed by aging were conversely regulated in the regenerated liver.

We next sought to examine the overrepresented biological processes of 95 significantly dysregulated genes

Table 2 Selected differentially up- or downregulated genes in both regenerated (RO) liver and hepatomas (DO) from old liver whose expression levels were also reset to those seen in normal young (NY) liver (Fig. 1a, region I)

\begin{tabular}{|c|c|c|c|c|}
\hline Gene & Gene name & $\mathrm{NY} / \mathrm{NO}^{\mathrm{a}}$ & $\mathrm{DO} / \mathrm{NO}^{\mathrm{b}}$ & $\mathrm{RO} / \mathrm{NO}^{\mathrm{b}}$ \\
\hline Dixdc1 & DIX domain containing 1 & -2.9 & -2.7 & -3.4 \\
\hline Ankk1 & Ankyrin repeat and kinase domain containing 1 & -3.0 & -2.3 & -3.2 \\
\hline Esm1 & Endothelial cell-specific molecule 1 & -5.2 & -3.4 & -3.2 \\
\hline Gpc2 & Glypican 2 & -3.7 & -3.6 & -3.1 \\
\hline Rhobtb2 & Rho-related BTB domain containing 2 & -2.1 & -2.8 & -2.8 \\
\hline Rpl28 & Ribosomal protein L28 & -2.9 & -3.3 & -2.7 \\
\hline Dlx 1 & Distal-less homeobox 1 & -2.7 & -2.4 & -2.6 \\
\hline Mbtps2 & Membrane-bound transcription factor peptidase, site 2 & -2.5 & -2.2 & -2.6 \\
\hline LACS & L-NAME induced actin cytoskeletal protein & -3.0 & -2.6 & -2.5 \\
\hline RGD1565996 & Similar to DnaJ homolog subfamily B member 6 (Heat shock protein J2) & -2.8 & -3.0 & -2.5 \\
\hline Tgm3 & Transglutaminase 3, E polypeptide & -3.1 & -3.5 & -2.5 \\
\hline Olr1393 & Olfactory receptor 1393 & -2.1 & -2.2 & -2.4 \\
\hline $\operatorname{Sen} 5 \mathrm{a}$ & Sodium channel, voltage-gated, type V, alpha polypeptide & -3.3 & -2.3 & -2.1 \\
\hline Eml4 & Echinoderm microtubule associated protein like 4 & 3.6 & 2.7 & 2.2 \\
\hline Nrp1 & Neuropilin 1 & 2.4 & 2.5 & 2.4 \\
\hline RGD1562100 & Similar to ADP-ribosylation factor interacting protein 2 (arfaptin 2) & 3.0 & 3.1 & 3.1 \\
\hline Caskin 1 & CASK-interacting protein 1 & 3.6 & 3.4 & 3.4 \\
\hline Cap350 & Centrosome-associated protein 350 & 8.1 & 3.5 & 3.4 \\
\hline
\end{tabular}

${ }^{\text {a }}$ Fold change (FC) was calculated between the mean values of NO (normal old) and NY (normal young)

${ }^{\mathrm{b}}$ Fold change (FC) was calculated between the mean values of NO (normal old) and DO (hepatoma) as well as RO (regenerated) 
Table 3 Top 38 genes that were most significantly dysregulated in regenerated old liver (excluding genes that are shared in hepatomas from old liver) whose expressions were reset to the normal young status (Fig. 1a, region III)

\begin{tabular}{|c|c|c|c|c|}
\hline Gene symbol & Gene name & Biological process & $\mathrm{FC} \mathrm{NY/NO}{ }^{\mathrm{a}}$ & $\mathrm{FC} \mathrm{RO} / \mathrm{NO}^{\mathrm{b}}$ \\
\hline Cspg2 & $\begin{array}{l}\text { Chondroitin sulfate } \\
\text { proteoglycan } 2\end{array}$ & $\begin{array}{l}\text { Cell motility | signal transduction | extracellular matrix } \\
\text { protein-mediated signaling; cell proliferation and dif- } \\
\text { ferentiation; cell structure and motility | cell } \\
\text { communication }\end{array}$ & -5.5 & -5.6 \\
\hline Grid1 & $\begin{array}{l}\text { Glutamate receptor, } \\
\text { ionotropic, delta } 1\end{array}$ & Synaptic transmission | transport | neuronal activities & -18.9 & -4.8 \\
\hline $\mathrm{T} 112$ & Tolloid-like 2 & $\begin{array}{l}\text { Proteolysis; signal transduction | protein metabolism and } \\
\text { modification | ligand-mediated signaling; develop- } \\
\text { mental processes | mesoderm development | cell com- } \\
\text { munication | skeletal development }\end{array}$ & -3.6 & -3.1 \\
\hline Zbtb16 & $\begin{array}{l}\text { Zinc finger and BTB } \\
\text { domain containing } 16\end{array}$ & $\begin{array}{l}\text { Nucleoside, nucleotide and nucleic acid metabolism | } \\
\text { mRNA transcription }\end{array}$ & -2.4 & -2.9 \\
\hline RGD1310257 & $\begin{array}{l}\text { Similar to RIKEN cDNA } \\
\text { 6330408A02 gene }\end{array}$ & $\begin{array}{l}\text { Protein metabolism and modification | proteolysis; } \\
\text { developmental processes | neurogenesis; cell } \\
\text { proliferation and differentiation | ectoderm } \\
\text { development }\end{array}$ & -2.6 & -2.9 \\
\hline Arrb2 & Arrestin, beta 2 & $\begin{array}{l}\text { Cell surface receptor-mediated signal transduction | sig- } \\
\text { nal transduction | G protein-mediated signaling; intra- } \\
\text { cellular protein traffic | endocytosis; sensory perception }\end{array}$ & -2.6 & -2.6 \\
\hline Cdkn1c & $\begin{array}{l}\text { Cyclin-dependent kinase } \\
\text { inhibitor } 1 \mathrm{C}\end{array}$ & $\begin{array}{l}\text { Tumor suppressor | cell cycle | cell cycle control; cell } \\
\text { proliferation and differentiation; oncogenesis }\end{array}$ & -3.2 & -2.6 \\
\hline Extl2 & Exotoses (multiple)-like 2 & $\begin{array}{l}\text { Other polysaccharide metabolism; protein metabolism } \\
\text { and modification | protein glycosylation | carbohydrate } \\
\text { metabolism }\end{array}$ & -3.8 & -2.6 \\
\hline $\operatorname{Slc} 25 \mathrm{a} 32$ & $\begin{array}{l}\text { Solute carrier family } 25, \\
\text { member } 32\end{array}$ & Small molecule transport $\mid$ transport & -2.2 & -2.5 \\
\hline Foxr1 & Forkhead box R1 & $\begin{array}{l}\text { Tissue development; embryo development; organ } \\
\text { development }\end{array}$ & -2.4 & -2.5 \\
\hline Ampd1 & $\begin{array}{l}\text { Adenosine monophosphate } \\
\text { deaminase } 1 \text { (isoform } \mathrm{M} \text { ) }\end{array}$ & $\begin{array}{l}\text { Nucleoside, nucleotide, and nucleic acid metabolism | } \\
\text { purine metabolism }\end{array}$ & -2.1 & -2.5 \\
\hline RGD1309049 & $\begin{array}{l}\text { Similar to RIKEN cDNA } \\
4933415 \mathrm{~F} 23\end{array}$ & $\begin{array}{l}\text { Protein phosphorylation; protein targeting and } \\
\text { localization | protein metabolism and modification | } \\
\text { protein targeting | protein modification }\end{array}$ & -2.2 & -2.4 \\
\hline Slc25a41 & $\begin{array}{l}\text { Solute carrier family } 25 \text {, } \\
\text { member } 41\end{array}$ & Small molecule transport | transport & -2.3 & -2.4 \\
\hline LOC500105 & $\begin{array}{l}\text { Similar to contactin } \\
\text { associated protein-like } 2 \\
\text { isoform a }\end{array}$ & $\begin{array}{l}\text { Synaptic transmission | signal transduction | cell } \\
\text { communication | cell adhesion-mediated signaling; cell } \\
\text { adhesion; neuronal activities }\end{array}$ & -2.3 & -2.3 \\
\hline Mlph & Melanophilin & General vesicle transport $\mid$ intracellular protein traffic & -3.0 & -2.3 \\
\hline Nek11 & $\begin{array}{l}\text { NIMA (never in mitosis } \\
\text { gene a)-related kinase } 11\end{array}$ & $\begin{array}{l}\text { Protein metabolism and modification | protein } \\
\text { modification | protein phosphorylation; phosphate } \\
\text { metabolism; other metabolism }\end{array}$ & -4.5 & -2.2 \\
\hline Cdkn1c & $\begin{array}{l}\text { Cyclin-dependent kinase } \\
\text { inhibitor 1C (P57) }\end{array}$ & $\begin{array}{l}\text { Tumor suppressor | cell cycle | cell cycle control; cell } \\
\text { proliferation and differentiation; oncogenesis }\end{array}$ & -2.9 & -2.2 \\
\hline Klk6 & Kallikrein 6 & Proteolysis | protein metabolism and modification & -2.2 & -2.1 \\
\hline Gja5 & $\begin{array}{l}\text { Gap junction membrane } \\
\text { channel protein alpha } 5\end{array}$ & Signal transduction & -2.6 & -2.1 \\
\hline Il21r & Interleukin 21 receptor & $\begin{array}{l}\text { Natural killer cell-mediated immunity | immunity } \\
\text { and defense }\end{array}$ & -2.4 & -2.1 \\
\hline Clca3 & $\begin{array}{l}\text { Chloride channel calcium } \\
\text { activated } 3\end{array}$ & ATP synthesis coupled proton transport & -2.3 & -2.1 \\
\hline Akr1c6 & $\begin{array}{l}\text { Aldo-keto reductase family } \\
\text { 1, member C6 }\end{array}$ & $\begin{array}{l}\text { Steroid hormone metabolism | steroid metabolism | fatty } \\
\text { acid biosynthesis; lipid, fatty acid, and steroid } \\
\text { metabolism | fatty acid metabolism | lipid, fatty acid, } \\
\text { and steroid metabolism }\end{array}$ & 2.8 & 2.1 \\
\hline
\end{tabular}


Table 3 (continued)

\begin{tabular}{|c|c|c|c|c|}
\hline Gene symbol & Gene name & Biological process & $\mathrm{FC} \mathrm{NY/NO}{ }^{\mathrm{a}}$ & $\mathrm{FC} \mathrm{RO} / \mathrm{NO}^{\mathrm{b}}$ \\
\hline Rshl2 & Radial spokehead-like 2 & $\begin{array}{l}\text { Signal transduction; intracellular protein traffic; protein } \\
\text { targeting and localization; miscellaneous }\end{array}$ & 2.1 & 2.3 \\
\hline Pde $8 b$ & Phosphodiesterase 8B & $\begin{array}{l}\text { Nucleoside, nucleotide and nucleic acid metabolism } \mid \\
\text { metabolism of cyclic nucleotides; signal transduction }\end{array}$ & 2.7 & 2.3 \\
\hline Cyp3a13 & $\begin{array}{l}\text { Cytochrome P450, family } 3 \text {, } \\
\text { subfamily a, polypeptide } \\
13\end{array}$ & $\begin{array}{l}\text { Steroid hormone metabolism; electron transport | steroid } \\
\text { metabolism | lipid, fatty acid, and steroid metabolism }\end{array}$ & 30.2 & 2.3 \\
\hline Tubg1 & Tubulin, gamma 1 & $\begin{array}{l}\text { Cell motility | chromosome segregation; cell structure } \\
\text { and motility | cell structure; cell structure and motility } \mid \\
\text { mitosis } \mid \text { intracellular protein traffic; cell cycle }\end{array}$ & 2.5 & 2.5 \\
\hline $\mathrm{Kb} 24$ & Type II keratin Kb24 & $\begin{array}{l}\text { Ectoderm development; cell structure and motility | cell } \\
\text { structure | developmental processes }\end{array}$ & 2.2 & 2.5 \\
\hline Pax3 & Paired box gene 3 & $\begin{array}{l}\text { Nucleoside, nucleotide, and nucleic acid metabolism | } \\
\text { mRNA transcription regulation; developmental } \\
\text { processes | segment specification; neurogenesis } \mid \\
\text { ectoderm development }\end{array}$ & 2.4 & 2.5 \\
\hline Gpr85 & $\begin{array}{l}\text { G protein-coupled receptor } \\
85\end{array}$ & $\begin{array}{l}\text { Cell surface receptor-mediated signal transduction } \mid \text { sig- } \\
\text { nal transduction | G protein-mediated signaling }\end{array}$ & 2.7 & 2.7 \\
\hline Fut11 & Fucosyltransferase 11 & $\begin{array}{l}\text { Protein metabolism and modification | protein } \\
\text { glycosylation | protein modification }\end{array}$ & 3.8 & 2.7 \\
\hline Pnpla6 & $\begin{array}{l}\text { Patatin-like phospholipase } \\
\text { domain containing } 6\end{array}$ & $\begin{array}{l}\text { Lipid, fatty acid, and steroid metabolism | other neuronal } \\
\text { activity | phospholipid metabolism; neuronal activities }\end{array}$ & 2.1 & 2.7 \\
\hline Nsddr & $\begin{array}{l}\text { Neural stem cell-derived } \\
\text { dendrite regulator }\end{array}$ & Biological process unclassified & 2.3 & 3.0 \\
\hline Nr1h2 & $\begin{array}{l}\text { Nuclear receptor subfamily } \\
1 \text {, group } \mathrm{H}, \text { member } 2\end{array}$ & $\begin{array}{l}\text { Transcription | regulation of transcription, DNA- } \\
\text { dependent | negative regulation of transcription | cel- } \\
\text { lular lipid metabolic process | positive regulation of } \\
\text { transcription, DNA-dependent | retinoic acid receptor } \\
\text { signaling pathway }\end{array}$ & 3.9 & 3.1 \\
\hline Ptk6 & $\begin{array}{l}\text { PTK6 protein tyrosine } \\
\text { kinase } 6\end{array}$ & $\begin{array}{l}\text { Protein phosphorylation; signal transduction | protein } \\
\text { metabolism and modification | protein modification | } \\
\text { intracellular signaling cascade; oncogenesis }\end{array}$ & 2.7 & 3.3 \\
\hline Itga5 & Integrin alpha 5 & Cell adhesion & 3.0 & 3.4 \\
\hline Olr813 & Olfactory receptor 813 & $\begin{array}{l}\text { Cell surface receptor-mediated signal transduction | sig- } \\
\text { nal transduction | G protein-mediated signaling; sen- } \\
\text { sory perception | olfaction | chemosensory perception }\end{array}$ & 2.3 & 3.8 \\
\hline Slc6a6 & Solute carrier family 6 & $\begin{array}{l}\text { Transport | small molecule transport; transport } \mid \\
\text { extracellular transport and import }\end{array}$ & 3.9 & 5.0 \\
\hline
\end{tabular}

${ }^{a}$ Fold change (FC) was calculated between the mean values of NO (normal old) and NY (normal young)

${ }^{\mathrm{b}}$ Fold change (FC) was calculated between the mean values of NO (normal old) and DO (hepatoma) as well as RO (regenerated)

shared in the regenerated liver and in normal aging, however, in the opposite direction. The biological processes of those genes include signal transduction ( $21 \%$ ), protein metabolism and modification (14\%), developmental process (13\%), transport, and cellular differentiation and proliferation (Fig. 2a). The most significantly enriched biological process categories include ectoderm and mesoderm development, developmental process, small molecule transport, and cell proliferation and differentiation $(p$ value $<0.05)$. Consistent with the categories identified by PANTHER, the IPA functional analysis also revealed cellular movement, embryonic development, lipid metabolism, small molecule biochemistry, cellular growth and proliferation, tissue development, and cellular development as significantly enriched functional categories (Fig. 2b).

Gene interaction network analysis of aging genes reset to young age by regeneration

To obtain a deeper insight into the interaction network and altered pathways, we mapped the 95 aging genes 
a

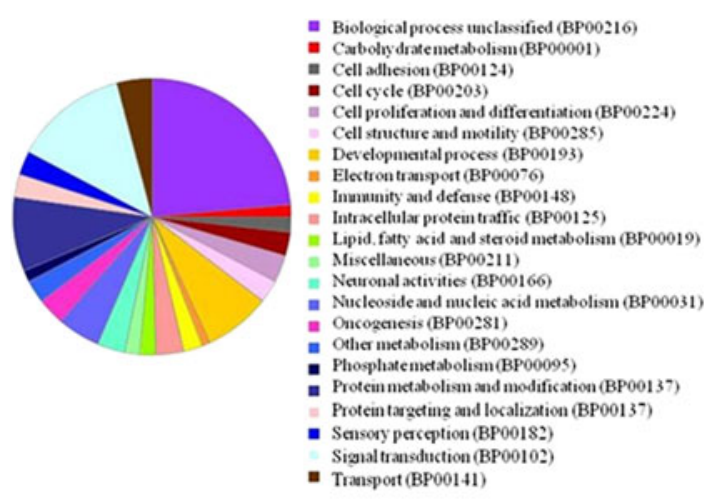

b
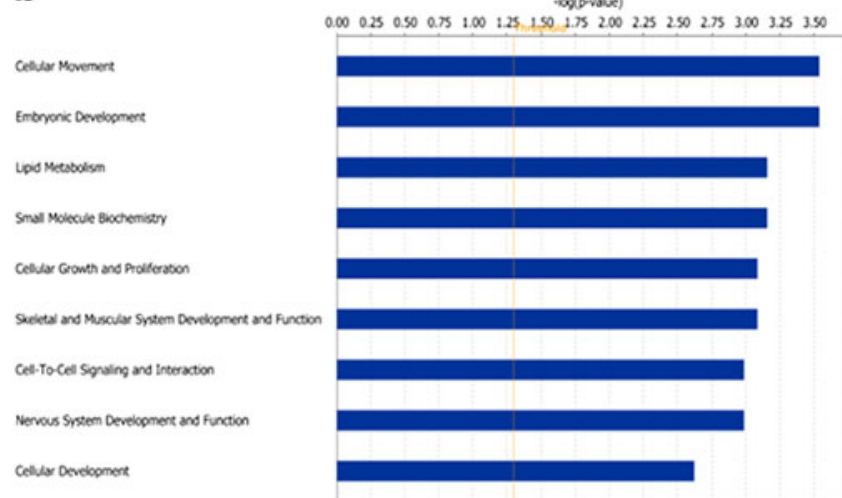

C

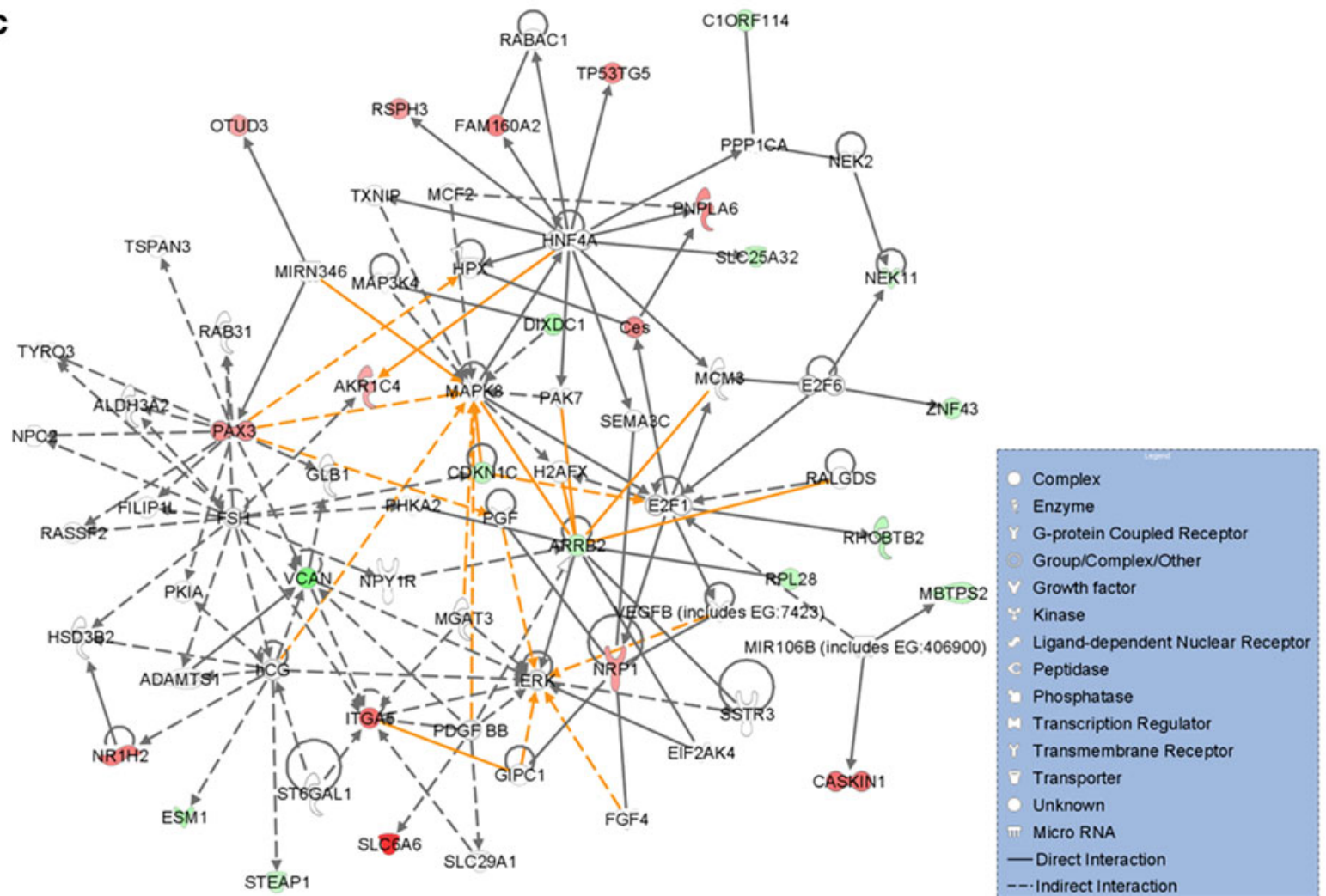

Fig. 2 Functional and network analyses of aging and regenerated liver transcriptome. PANTHER pie chart of biological processes (a), significantly enriched functional categories (b), and gene interaction network (c) analysis of regenerationspecific up/downregulated genes that are also common to normal aging genes, and whose expressions were reset to the normal young status. b $X$-axis indicates the significance (-log $p$ value) of the functional association that is dependent on the

whose expression was set to young age by regeneration to gene networks using the ingenuity knowledge base. These genes were mapped primarily to top networks (Fig. 2c) related to, among others, cellular movement, number of genes in a class as well as biologic relevance. c Nodes represent genes, with their shape representing the functional class of the gene product, and edges indicate biological relationship between the nodes (see legend). Green indicates downregulated; red, upregulated in RO (regenerated). The color intensity is correlated with fold change. Straight lines are for direct gene-to-gene interactions, dashed lines are for indirect ones

embryonic development, cellular growth and proliferation, tissue development, lipid metabolism, and small molecule biochemistry. Our gene network analysis indicated important roles of $P A X 3, E 2 F 1$, ITGA5, MAPK, and 
$V C A N$ that are interacting with many other genes that we have identified in this study.

Validation of the results in independent HCC datasets and comparison to calorie restriction studies

As a validation of our results, we re-analyzed three independently performed microarray datasets for human HCC (Wurmbach et al. 2007; Boyault et al. 2007; Mas et al. 2009). The comparison of our rat HCC genes (human orthologous) with the re-analyzed human HCC datasets revealed a significant number of genes in common ( $p$ value $<0.001$ ). Furthermore, we obtained consistent results with two independent studies of DENinduced HCC in rats (Perez-Carreon et al. 2006; Liu et al. 2009). The functional and gene ontology analyses of all validation datasets revealed a significant number of overrepresented functional categories in common with our results. Of note, cell death, cancer, cellular development, cellular growth and proliferation, organismal development, transport, and cell cycle came up as significantly enriched categories in both the validation datasets and our analyses.

To further validate, we compared our results with independently performed microarray studies for aging and calorie restriction. Most recently, Hong et al. (2010) gathered genes related to aging and calorie restriction (CR) from numerous published studies and from microarray datasets in the GEO repository. We found that a significant number of our aging genes were in common with our analysis results ( $p$ value $<0.05$ ). Furthermore, a significant number of over-represented gene ontology (GO) terms in aging from our analysis were retained in the validation set. For example, immune response, cell adhesion, lipid metabolism, cellular development, nervous system development and function, cell-to-cell signaling, and skeletal and muscular system development and function come up as significantly enriched GO categories in both the validation and our analysis. Hence, the similarities between our results and the independent validation sets argue against random chance accounting for the observed enrichment of these functional categories and pathways.

Validation of selected differentially expressed genes using real-time RT-PCR

We used quantitative real-time RT-PCR to validate our microarray results for eight randomly selected genes
(E2f5, Cep350, Nrp1, Esm1, Cltb, Caskin1, Wit3, and Ube2l6) (Table 4). A significant correlation existed between the microarray and real-time RT-PCR results $(r>0.74, p$ value $<0.03)$. We also validated expression levels of another set of six randomly selected differentially regulated genes (Pbsn, Cdh13, Lum, Nid2, Dcn, Slc22a5) in our earlier study (Colak et al. 2010). In all cases, a high concordance existed between the microarray and real-time RT-PCR results thus demonstrating the reliability of our gene expression measurements.

\section{Discussion}

The present study sought to investigate if the proliferation in old rat liver can reset the levels of expression of aging-related genes to that observed in young tissue using global gene expression profiling. We developed a rat model of liver regeneration post-hepatectomy (return to quiescence), as well as liver cells undergoing malignant transformation, and compared them to normal liver using a comprehensive microarray of 27,000 publicly available and Celera annotated rat genes. We have found evidence that over $20 \%$ of the aging-related genes had their levels of expression reset to young levels by stimulating proliferation, even in cells that had undergone a limited number of cell cycles and then become quiescent again. Importantly, we identified genes and pathways significantly altered with aging and regeneration that are distinct from cancer.

Aging is a complex process characterized by a gradual and progressive decay of biochemical and physiological functions of most organs. Our data revealed that genes associated with immune and stress response were activated with aging, whereas genes associated with lipid metabolism, cellular growth and maintenance, protein synthesis, and cellular communication were downregulated, consistent with other independent studies, such as gene expression in human retina (Yoshida et al. 2002), gene expression profiling of aging rat liver (Tollet-Egnell et al. 2001), age-associated changes in gene expression in human liver (Thomas et al. 2002), and mouse transcriptome (Hong et al. 2010; Schumacher et al. 2008). The functional pathways were also consistent with previous studies. However, the novelty of our approach is that we identified a novel group of genes and altered pathways involved in regeneration and hepatoma as 
Table 4 Validation of selected differentially expressed genes using real-time RT-PCR

\begin{tabular}{|c|c|c|c|c|c|c|c|}
\hline \multirow[t]{2}{*}{ Gene symbol } & \multirow[t]{2}{*}{ Description } & \multicolumn{2}{|c|}{ Hepatoma (DO/NO) } & \multicolumn{2}{|c|}{ Regenerated (RO/NO) } & \multicolumn{2}{|c|}{ Normal aging $(\mathrm{NO} / \mathrm{NY})$} \\
\hline & & qRTPCR & Microarray & qRTPCR & Microarray & qRTPCR & Microarray \\
\hline Caskin1 & Cask-interacting protein 1 & 10.1 & 3.4 & 10.3 & 3.4 & -4.9 & -3.6 \\
\hline Wit3.0 & Wound inducible transcript 3.0 & 6.8 & 1.4 & 4 & 1.5 & -3.9 & -1.6 \\
\hline Cltb & Clathrin, light polypeptide (Lcb) & 7.4 & 1.6 & 4.6 & 2.5 & -1.7 & -1.8 \\
\hline Nrp1 & Neuropilin 1 & 1.4 & 2.5 & 3.1 & 2.4 & -2.3 & -2.5 \\
\hline Cep350 & Centrosome-associated protein 350 & 1.4 & 3.5 & 2.5 & 3.4 & -2.3 & -8.1 \\
\hline Esm1 & Endothelial cell-specific molecule 1 & -1.8 & -3.4 & -1.8 & -3.2 & 10 & 5.2 \\
\hline Ube216 & Ubiquitin-conjugating enzyme E2L 6 & -2.5 & -3.8 & -3.3 & -2.6 & 1.8 & 3 \\
\hline E2f5 & E2F transcription factor 5 & -1.4 & -2.5 & -1.8 & -1.9 & 1.4 & 4.3 \\
\hline
\end{tabular}

well as in aging and found genes differentially regulated in both regenerated and hepatomas from old liver, as well as uniquely dysregulated genes in hepatoma and regenerated whose expressions were reset to that seen in normal young. Intriguingly, the comparison of normal aging genes with the significantly dysregulated genes in the regenerated old liver revealed that the expression levels of over $90 \%$ of shared genes had displayed similar levels to those seen in the normal young liver than old liver. This occurred in hepatoma cells that were actively proliferating (Charlton et al. 1999) and, more importantly, also in cells from regenerated liver lobes that had undergone a limited number of cell divisions and then resumed a quiescent state. The gene ontological analysis revealed that the regeneration-specific genes were mainly associated with lipid metabolism, mRNA transcription and regulation, protein modification, protein phosphorylation, cell morphology, cellular development, small molecule biochemistry, and cellular growth and proliferation. Thus, the genes and processes activated or repressed by aging were conversely regulated in the regenerated liver.

CR diet has been shown to have effects on lifespan prolongation, mitochondrial autophagy, cell adaptation to hypoxia, and antineoplastic effects ( $\mathrm{Li}$ et al. 1997; Cao et al. 2001). Hence, we investigated if there are any similarities between calorie restriction and regeneration-related gene expression changes, as both have demonstrated a reversal of gene expression changes due to aging. Studies on CR-related longevity indicate a number of genes, including silent information regulator 2 (Sir2), Sirtuin 1, forkhead box
(FOXO1), that are involved in antineoplastic effects; whereas, FoxM1B transcription factors prevent agerelated proliferation defects (Wang et al. 2001; Nasarre et al. 2010; Yamaza et al. 2010). Recently, proteomic profiling was done in aging rat white adipose tissue, and calorie restriction reversed the aging-related protein alteration. Calorie restriction improves the oxidative stress, cellular and energy metabolism, iron storage, and antioxidant affects (Valle et al. 2010). The comparison of CR and our regenerated-related genes that reset the aging genes revealed over-representation of genes related to lipid metabolism, cellular growth and proliferation, transcription, cell adhesion, and response to stimulus (Hong et al. 2010).

Our functional pathway and network analysis of aging genes whose expression was reversed by regeneration indicated alterations in MAPK/ERK and JunN-terminal kinase (JNK) pathways. Recent studies have identified the JNK pathway as a regulator of insulin/insulin-like growth factor signaling and influencing growth, metabolism, stress tolerance, and regeneration (Wang et al. 2005, 2003; Karpac et al. 2009). Interestingly, moderate activation of JNK signaling resulted in increased stress tolerance and extended life span in various organisms (Wang et al. 2005, 2003). Moreover, our network analysis also indicated potential important roles of $P A X 3, V C A N$, ARRB2, ITGA5, and NR1H2 that are interacting with many other genes that we have identified in this study. These genes are known to be involved in proliferation, organismal development, and cell adhesion in a wide variety of cell types (Anderson et al. 2001; Matsumura et al. 2003; Conboy et al. 2011). Interestingly, liver X 
receptor beta (LXR- $\beta$ ) is a member of the nuclear receptor family of transcription factors and encoded by the NR1H2 gene (nuclear receptor subfamily 1 , group $\mathrm{H}$, member 2). LXR- $\beta$ is a close human homologue of daf-12, a regulator of nematode longevity, and is a key regulator of macrophage function, controlling transcriptional programs involved in lipid homeostasis and inflammation (Gerisch et al. 2001; Ly et al. 2000; Gems et al. 1998; Chang et al. 2008). It is therefore possible that these genes were influential in producing the changes in gene expression we have observed as a result of inducing proliferation in old liver and hence warrant further study.

In conclusion, to our knowledge, this is the first study to examine global gene expression patterns in normal aging and regenerated old liver differentiated from hepatic liver and demonstrates that by inducing cells to proliferate, it is possible to reset the gene expression levels in old rat liver to that observed in normal young liver for many of the differentially expressed genes. This occurred in malignant cells that were actively proliferating and also in cells from regenerated liver lobes that had undergone a limited number of cell divisions and then resumed a quiescent state. Intriguingly, the cells do not need to be actively proliferating to maintain the reset state. It is unknown which aspect of cell proliferation is responsible for this effect. However, if this can be identified in future research, then it may prove possible to develop an intervention that can produce an anti-aging effect.

Acknowledgments The authors wish to thank Dr. Maqbool Ahmad for his kind help in RNA isolation. We would like to thank the King Faisal Specialist Hospital and Research Center for the financial support. This project is supported by King Faisal Specialist Hospital and Research Center's seed grants and Deanship of Scientific Research, King Saud University.

Open Access This article is distributed under the terms of the Creative Commons Attribution License which permits any use, distribution, and reproduction in any medium, provided the original author(s) and the source are credited.

\section{References}

Anderson J, Ramsay A, Gould S, Pritchard-Jones K (2001) PAX3FKHR induces morphological change and enhances cellular proliferation and invasion in rhabdomyosarcoma. Am J Pathol 159(3):1089-1096. doi:10.1016/S0002-9440(10)61784-1

Boyault S, Rickman DS, de Reynies A, Balabaud C, Rebouissou S, Jeannot E, Herault A, Saric J, Belghiti J, Franco D,
Bioulac-Sage P, Laurent-Puig P, Zucman-Rossi J (2007) Transcriptome classification of HCC is related to gene alterations and to new therapeutic targets. Hepatol (Baltimore, Md) 45(1):42-52. doi:10.1002/hep.21467

Cao SX, Dhahbi JM, Mote PL, Spindler SR (2001) Genomic profiling of short- and long-term caloric restriction effects in the liver of aging mice. Proc Natl Acad Sci USA 98(19):10630-10635. doi:10.1073/pnas. 191313598191313598

Chang KC, Shen Q, Oh IG, Jelinsky SA, Jenkins SF, Wang W, Wang Y, LaCava M, Yudt MR, Thompson CC, Freedman LP, Chung JH, Nagpal S (2008) Liver X receptor is a therapeutic target for photoaging and chronological skin aging. Mol Endocrinol 22(11):2407-2419. doi:10.1210/ me.2008-0232

Charlton MA, Merry BJ, Goyns MH (1999) Differential display analysis can reveal patterns of gene expression in immortalised hepatoma cells which are similar to those observed in young adult but not old adult liver cells. Cancer Lett 143 (1):45-50

Colak D, Chishti MA, Al-Bakheet AB, Al-Qahtani A, Shoukri MM, Goyns MH, Ozand PT, Quackenbush J, Park BH, Kaya N (2010) Integrative and comparative genomics analysis of early hepatocellular carcinoma differentiated from liver regeneration in young and old. Mol Cancer 9:146. doi:10.1186/1476-4598-9-146

Conboy IM, Yousef H, Conboy MJ (2011) Embryonic antiaging niche. Aging (Albany NY) 3(5):555-563

Gems D, Sutton AJ, Sundermeyer ML, Albert PS, King KV, Edgley ML, Larsen PL, Riddle DL (1998) Two pleiotropic classes of daf-2 mutation affect larval arrest, adult behavior, reproduction and longevity in Caenorhabditis elegans. Genetics 150(1):129-155

Gentleman RC, Carey VJ, Bates DM, Bolstad B, Dettling M, Dudoit S, Ellis B, Gautier L, Ge Y, Gentry J, Hornik K, Hothorn T, Huber W, Iacus S, Irizarry R, Leisch F, Li C, Maechler M, Rossini AJ, Sawitzki G, Smith C, Smyth G, Tierney L, Yang JY, Zhang J (2004) Bioconductor: open software development for computational biology and bioinformatics. Genome Biol 5(10):R80. doi:10.1186/gb-2004-510-r80

Gerisch B, Weitzel C, Kober-Eisermann C, Rottiers V, Antebi A (2001) A hormonal signaling pathway influencing C. elegans metabolism, reproductive development, and life span. Dev Cell 1(6):841-851

Goyns MH (2002) Genes, telomeres and mammalian ageing. Mech Ageing Dev 123(7):791-799

Goyns MH, Charlton MA, Dunford JE, Lavery WL, Merry BJ, Salehi M, Simoes DC (1998) Differential display analysis of gene expression indicates that age-related changes are restricted to a small cohort of genes. Mech Ageing Dev 101 (1-2):73-90

Hong SE, Heo HS, Kim DH, Kim MS, Kim CH, Lee J, Yoo MA, Yu BP, Leeuwenburgh C, Chung HY (2010) Revealing system-level correlations between aging and calorie restriction using a mouse transcriptome. Age (Dordr) 32 (1):15-30. doi:10.1007/s11357-009-9106-3

Ito N, Hirose M, Shibata M, Tanaka H, Shirai T (1989) Modifying effects of simultaneous treatment with butylated hydroxyanisole (BHA) on rat tumor induction by $3,2^{\prime}$ dimethyl-4-aminobiphenyl, 2,2'-dihydroxy-di-n- 
propylnitrosamine and N-methylnitrosourea. Carcinogenesis 10(12):2255-2259

Karpac J, Hull-Thompson J, Falleur M, Jasper H (2009) JNK signaling in insulin-producing cells is required for adaptive responses to stress in Drosophila. Aging Cell 8(3):288295. doi:10.1111/j.1474-9726.2009.00476.x

Kayo T, Allison DB, Weindruch R, Prolla TA (2001) Influences of aging and caloric restriction on the transcriptional profile of skeletal muscle from rhesus monkeys. Proc Natl Acad Sci USA 98(9):5093-5098. doi:10.1073/pnas. 081061898081061898

Kume S, Uzu T, Horiike K, Chin-Kanasaki M, Isshiki K, Araki S, Sugimoto T, Haneda M, Kashiwagi A, Koya D (2010) Calorie restriction enhances cell adaptation to hypoxia through Sirt1-dependent mitochondrial autophagy in mouse aged kidney. J Clin Invest 120(4):1043-1055. doi:10.1172/JCI41376

Lee CK, Klopp RG, Weindruch R, Prolla TA (1999) Gene expression profile of aging and its retardation by caloric restriction. Science 285(5432):1390-1393

Lee CK, Weindruch R, Prolla TA (2000) Gene-expression profile of the ageing brain in mice. Nat Genet 25(3):294-297. doi:10.1038/77046

Lee CK, Allison DB, Brand J, Weindruch R, Prolla TA (2002) Transcriptional profiles associated with aging and middle age-onset caloric restriction in mouse hearts. Proc Natl Acad Sci USA 99(23):14988-14993. doi:10.1073/pnas. 232308999232308999

Li Y, Yan Q, Wolf NS (1997) Long-term caloric restriction delays age-related decline in proliferation capacity of murine lens epithelial cells in vitro and in vivo. Invest Ophthalmol Vis Sci 38(1):100-107

Liu YF, Zha BS, Zhang HL, Zhu XJ, Li YH, Zhu J, Guan XH, Feng ZQ, Zhang JP (2009) Characteristic gene expression profiles in the progression from liver cirrhosis to carcinoma induced by diethylnitrosamine in a rat model. J Exp Clin Cancer Res 28:107. doi:10.1186/1756-9966-28-107

Livak KJ, Schmittgen TD (2001) Analysis of relative gene expression data using real-time quantitative PCR and the 2(-Delta Delta C(T)) method. Methods 25(4):402-408

Lu T, Pan Y, Kao SY, Li C, Kohane I, Chan J, Yankner BA (2004) Gene regulation and DNA damage in the ageing human brain. Nature 429(6994):883-891. doi:10.1038/ nature02661 nature 02661

Ly DH, Lockhart DJ, Lerner RA, Schultz PG (2000) Mitotic misregulation and human aging. Science 287(5462):24862492

Mas VR, Maluf DG, Archer KJ, Yanek K, Kong X, Kulik L, Freise CE, Olthoff KM, Ghobrial RM, McIver P, Fisher R (2009) Genes involved in viral carcinogenesis and tumor initiation in hepatitis $\mathrm{C}$ virus-induced hepatocellular carcinoma. Mol Med 15(3-4):85-94

Masoro EJ (1992) Retardation of aging processes by food restriction: an experimental tool. Am J Clin Nutr 55(6 Suppl):1250S$1252 \mathrm{~S}$

Matsumura I, Tanaka H, Kanakura Y (2003) E2F1 and c-Myc in cell growth and death. Cell Cycle 2(4):333-338

Mori K, Blackshear PE, Lobenhofer EK, Parker JS, Orzech DP, Roycroft JH, Walker KL, Johnson KA, Marsh TA, Irwin RD, Boorman GA (2007) Hepatic transcript levels for genes coding for enzymes associated with xenobiotic metabolism are altered with age. Toxicol Pathol 35 (2):242-251. doi:10.1080/01926230601156286

Nasarre C, Roth M, Jacob L, Roth L, Koncina E, Thien A, Labourdette G, Poulet P, Hubert P, Cremel G, Roussel G, Aunis D, Bagnard D (2010) Peptide-based interference of the transmembrane domain of neuropilin-1 inhibits glioma growth in vivo. Oncogene 29(16):2381-2392. doi:10.1038/ onc. 2010.9

Perez-Carreon JI, Lopez-Garcia C, Fattel-Fazenda S, Arce-Popoca E, Aleman-Lazarini L, Hernandez-Garcia S, Le Berre V, Sokol S, Francois JM, Villa-Trevino S (2006) Gene expression profile related to the progression of preneoplastic nodules toward hepatocellular carcinoma in rats. Neoplasia 8 (5):373-383

Rodwell GE, Sonu R, Zahn JM, Lund J, Wilhelmy J, Wang L, Xiao W, Mindrinos M, Crane E, Segal E, Myers BD, Brooks JD, Davis RW, Higgins J, Owen AB, Kim SK (2004) A transcriptional profile of aging in the human kidney. PLoS Biol 2(12):e427. doi:10.1371/journal. pbio.0020427

Saeed AI, Sharov V, White J, Li J, Liang W, Bhagabati N, Braisted J, Klapa M, Currier T, Thiagarajan M, Sturn A, Snuffin M, Rezantsev A, Popov D, Ryltsov A, Kostukovich E, Borisovsky I, Liu Z, Vinsavich A, Trush V, Quackenbush J (2003) TM4: a free, open-source system for microarray data management and analysis. Biotechniques 34(2):374378

Salehi M, Hodgkins MA, Merry BJ, Goyns MH (1996) Agerelated changes in gene expression in the rat brain revealed by differential display. Experientia 52(9):888-891

Schumacher B, van der Pluijm I, Moorhouse MJ, Kosteas T, Robinson AR, Suh Y, Breit TM, van Steeg H, Niedernhofer LJ, van Ijcken W, Bartke A, Spindler SR, Hoeijmakers JH, van der Horst GT, Garinis GA (2008) Delayed and accelerated aging share common longevity assurance mechanisms. PLoS Genet 4(8):e1000161. doi:10.1371/journal. pgen. 1000161

Swindell WR (2008) Genes regulated by caloric restriction have unique roles within transcriptional networks. Mech Ageing Dev 129(10):580-592. doi:10.1016/j.mad.2008.06.001

Tanaka F, Hori N, Sato K (2002) Identification of differentially expressed genes in rat hepatoma cell lines using subtraction and microarray. J Biochem 131(1):39-44

Thomas RP, Guigneaux M, Wood T, Evers BM (2002) Ageassociated changes in gene expression patterns in the liver. J Gastrointest Surg 6(3):445-453, Discussion, 454

Thomas PD, Campbell MJ, Kejariwal A, Mi H, Karlak B, Daverman R, Diemer K, Muruganujan A, Narechania A (2003) PANTHER: a library of protein families and subfamilies indexed by function. Genome Res 13(9):21292141

Thomas PD, Kejariwal A, Guo N, Mi H, Campbell MJ, Muruganujan A, Lazareva-Ulitsky B (2006) Applications for protein sequence-function evolution data: mRNA/protein expression analysis and coding SNP scoring tools. Nucleic Acids Res 34:W645-W650, Web Server issue

Tollet-Egnell P, Flores-Morales A, Stahlberg N, Malek RL, Lee N, Norstedt G (2001) Gene expression profile of the aging process in rat liver: normalizing effects of growth hormone replacement. Mol Endocrinol 15(2):308318 
Valle A, Sastre-Serra J, Roca P, Oliver J (2010) Modulation of white adipose tissue proteome by aging and calorie restriction. Aging Cell 9(5):882-894. doi:10.1111/j.14749726.2010.00613.x

Wang X, Quail E, Hung NJ, Tan Y, Ye H, Costa RH (2001) Increased levels of forkhead box M1B transcription factor in transgenic mouse hepatocytes prevent age-related proliferation defects in regenerating liver. Proc Natl Acad Sci USA 98(20):11468-11473. doi:10.1073/pnas.20136089898/ 20/11468

Wang MC, Bohmann D, Jasper H (2003) JNK signaling confers tolerance to oxidative stress and extends lifespan in Drosophila. Dev Cell 5(5):811-816

Wang MC, Bohmann D, Jasper H (2005) JNK extends life span and limits growth by antagonizing cellular and organismwide responses to insulin signaling. Cell 121(1):115-125. doi:10.1016/j.cell.2005.02.030

Wayneforth HB (ed) (1980) Experimental and surgical techniques in the rat. Academic, New York

Welle S, Brooks AI, Delehanty JM, Needler N, Thornton CA (2003) Gene expression profile of aging in human muscle. Physiol
Genomics 14(2):149-159. doi:10.1152/physiolgenomics. 00049.200300049 .2003

Wurmbach E, Chen YB, Khitrov G, Zhang W, Roayaie S, Schwartz M, Fiel I, Thung S, Mazzaferro V, Bruix J, Bottinger E, Friedman S, Waxman S, Llovet JM (2007) Genome-wide molecular profiles of $\mathrm{HCV}$-induced dysplasia and hepatocellular carcinoma. Hepatol (Baltimore, Md) 45(4):938-947

Yamaza H, Komatsu T, Wakita S, Kijogi C, Park S, Hayashi H, Chiba T, Mori R, Furuyama T, Mori N, Shimokawa I (2010) FoxO1 is involved in the antineoplastic effect of calorie restriction. Aging Cell 9(3):372-382. doi:10.1111/ j.1474-9726.2010.00563.x

Yoshida S, Yashar BM, Hiriyanna S, Swaroop A (2002) Microarray analysis of gene expression in the aging human retina. Invest Ophthalmol Vis Sci 43(8):2554-2560

Zahn JM, Sonu R, Vogel H, Crane E, Mazan-Mamczarz K, Rabkin R, Davis RW, Becker KG, Owen AB, Kim SK (2006) Transcriptional profiling of aging in human muscle reveals a common aging signature. PLoS Genet 2(7):e115. doi:10.1371/journal.pgen.0020115.eor 